DOI: $10.17951 /$ bc.2020.5.29-40

\begin{tabular}{lcr}
\hline & ANNALES \\
& UNIVERSITATIS MARIAE CURIE-SKLODOWSKA & \\
LUBLIN - POLONIA & \\
VOL.V & SECTIO M & 2020 \\
\hline
\end{tabular}

\author{
Tomasz Wicha \\ Maria Curie-Skłodowska University, Lublin \\ tomasz.wicha@interia.pl \\ ORCID ID: https://orcid.org/0000-0003-3547-2238
}

\title{
Overcoming political conflicts and competitions in favour of international cooperation - the project of Europe of the Carpathians and the project of The Three Seas Initiative
}

\section{Introductory remarks}

The research goal of the study is the presentation and comparison of two political projects which were aimed at strengthening the cooperation among Central and Eastern Europe states - Europe of the Carpathians and The Three Seas Initiative. Both projects were formed in the 2010s and the outcome of both of them is yet to be evaluated as the cooperation of the states in Central and Eastern Europe is not a finished plan but a challenge which is in progress and which may be expanded and specified.

The author focuses on the presentation of both projects. They are neither complementary nor contradictory. Both are created to lead to further cooperation which will make the states flourish. While the project of Europe of the Carpathians focused on global issues, academic and professional debates, the idea which stood behind the project of the Three Seas Initiative was pragmatic and very particular - there were specific means which the states wanted to introduce. The scientific challenge of the study is the intellectual relation of the projects and the goal which was similar in both of them - the formation of animation of the states of Central and Eastern Europe. 


\section{The project of Europe of the Carpathians}

The foreign affairs of the Republic of Poland is an issue in which there are strong arguments. Nevertheless, there were some cores on which the presence of the state and its prestige were built. One strict key concept is cooperation with the United States of America ${ }^{1}$. After World War II it was impossible for the Republic of Poland to set positive relations with other states as Poland was in the zone of the Soviet Union and the totalitarian regime made it impossible to establish equal relations because Poland was not an independent state ${ }^{2}$.

The concept which formed the basis for the cooperation between the states of Central and Eastern Europe had one joint argument which connected the states of that part of the continent: fear of the Russian Federation. Still, there are some problems in clarifying what might be cohesive to divergent states with differing cultures and disparate nations ${ }^{3}$.

The concept of closer relations between the states of Central and Eastern Europe was put forward in the conferences of the Europe of the Carpathians which were the part of the Economic Forum in Krynica-Zdrój in Poland, as well as in intellectual gatherings in Krasiczyn and Przemyśl ${ }^{4}$. The challenge of the whole project was to find ways, methods and financing for projects that may bring together the nations and states of Central Europe ${ }^{5}$. In such debates, Marek Kuchciński emphasised that Europe must be understood as a territory of different organizations and institutions.

The experience of more than a decade after $1^{\text {st }}$ May, 2004 made it necessary to rethink the project of the European Union. Therefore, the Europe of the Carpathians gathering seemed to have the intent of supporting and keeping at high level, integration between member-states of the European Union ${ }^{6}$. The solution was to limit the economic differences between member states ${ }^{7}$.

1 M. A. Cichocki, Lech Kaczyński i polityka zagraniczna, [in:] Lech Kaczyński - portret, M. Karnowski (ed.), Kraków 2010, p. 234.

2 J. Sanecka-Tyczyńska, Racja stanu we wspótczesnej polskiej myśli politycznej 2001-2015, Lublin 2018, p. 320.

3 M. Waldenberg, Kwestie narodowe w Europie Środkowo-Wschodniej. Dzieje. Idee, Warszawa 1992, passim.

4 M. Kuchciński, Stowo wstępne, [in:] Europa Karpat. Rzecz o wspótpracy, W. Paruch (ed.), Warszawa 2017, p. 5-6.

5 The website of Karpaty tacza, http://www.karpatylacza.pl.

6 K. Szczerski, Zadania dla polityki środkowoeuropejskiej, [in:] Europa Karpat. Rzecz o wspótpracy, W. Paruch (ed.), Warszawa 2017, p. 53.

7 R. Legutko, Po pierwsze suwerenność, [in:] Lech Kaczyński, Pamięć i zobowiq̨anie, Warszawa 2011, p. 19-23. 
Many intellectuals engaged in the project of Europe of the Carpathians stressed that the level of cooperation in Europe should not be limited to verbal presentation of the corporation, but ought to go beyond the physical interpretation of national interests. Hence, the philosophical character of the states that share similar history would encourage integration that would later enhance democratic values within the European Union.

The project 'Europe of the Carpathians' was therefore created not only for philosophical cooperation, but to induce real change and renewal. Those attending Europe of the Carpathians found it to be an appropriate venue for assessing European cooperation, and attendees were unanimous in stating that the prospect of the cooperation would be fruitful only after a thorough analysis of the problems besetting Europe, and then setting an agenda of remedy.

Europe of the Carpathians is an entity at the geopolitical centre of Central and Eastern Europe and, simultaneously, the centre of the geopolitical region between the Seas: the Baltic Sea, the Adriatic Sea and the Black Sea ${ }^{8}$. The initiative of the greening of the Europe of the Carpathians dates back to 1999-2000 when the programme of "Green Carpathians" was introduced by the governor of Podkarpackie Voivodeship?.

That idea of the sustainable development of the Carpathians was the point of reference at the Convention on protection the development of the Carpathians that was held on $22^{\text {nd }}$ May, 2003 in Kiev. The Carpathians, similarly to the Alps, were perceived as unique habitat and the demand for closer cooperation in their protection and promotion between the states of Central and Eastern Europe was present ${ }^{10}$.

In subsequent meetings it was widely stressed that the needs and the interest of the nations of the Carpathians were comparable and the frontiers did have significant impact. The initiative of the Europe of the Carpathians was introduced to overcome the differences between the states of the "old" European Union and new member-states of the European Union. The first phase of the establishment of the project of Europe of the Carpathians was finished by meeting in Warsaw in November 2007.

During the period of 2007-2011, the project was institutionalized in the political, social and organisational context, as it was widely perceived that the political identity and national values were similar in the states of the Central

8 The website of $W$ meritum, http://www.wmeritum.pl.

9 W. Paruch, Europa Karpat, Warsaw 2016, passim.

10 R. Terlecki, Europa naszej przyszłości, [in:] Europa Karpat. Rzecz o wspótpracy, W. Paruch (ed.), Warszawa 2017, p. 13-14. 
and Eastern Europe. Moreover, there was significant activity in the international arena, of politicians, experts and scientists engaged in the project. What joined participating states of the Central and Eastern Europe was geopolitical location and fear of the activities of the Russian Federation - fear that arose because of borderland history and Russian activity in Georgia.

Marek Kuchciński and other politicians of Poland's Law and Justice party and partners had planned to raise the political value of Europe of the Carpathians in 2010, but because of the Smoleńsk air disaster, that idea was postponed into 2011, and in 2011, the first International Conference of Europe of the Carpathians took place as a part of the Economic Forum in Krynica-Zdrój on 2011.

The meeting organised by the Deputy of the Polish Sejm in Krynica-Zdrój finished with the introduction of the Carpathian Memorandum. The implication of the Carpathian Memorandum was the sentence expressis verbis - that there was the necessity to form a Strategy for the Carpathians that would have not only have a regional and local, but also a European format. The result was a recommendation for the officials of the European Union that the Strategy for the Carpathians be one of the instruments of the European Union for macroregional policy in congruence with the rules of sustainable development and subsidiary.

The project of Europe of the Carpathians began to be a place for passionate discussion about the challenges faced by the European Union and the meaning of parliamentary diplomacy. One outcome of the abovementioned part of the Economic Forum in Krynica-Zdrój and Krasiczyn in Podkarpackie Voivodeship in the Republic of Poland was that Marek Kuchciński became the head of the Parliamentary Group of the Carpathians.

With time, the topics addressed in this forum were extended. At the very beginning, the context of cross-border and international economic cooperation was dominant; from 2013 on, the key topic was the political level of the cooperation. The scope of the interest of the participants of the project also changed throughout the time. One of the top priorities of the forums in 2014, 2015 and 2016 was the concept of security that, after the conflict on Ukraine, seemed a very problematic issue for the states of the Central and Eastern Europe.

Tourism was another area of would-be cooperation. There were plenty of opportunities by the organizations in the region of the Carpathians to work together in this sphere. In the international conference in Nowy Targ "Europe is enriched by the Carpathians", there was a discussion on the concept of the policy of development of euroregions, the policy of development of the tourist potential of the mountain ranges, discussions on reconstruction of infrastructure in the region of Central and Eastern Europe (roads, railway), and on extending cooperation to enhance tourism and to promote security in the European states. 
One of the most substantial outcomes of the conferences on Europe of the Carpathians was the introduction of "the Carpathian brand"11.

The year 2013 proved to be a turning point in the project of Europe of the Carpathian. At this time a workable strategy for enhancing the value and security of the region was introduced. The recommendations set out in the operational programme "Horizon of the Carpathians 2020" included a roadmap to design and then build a communications network from Thessaloniki in Greece through Bulgaria, Romania, Hungary, Slovakia, Poland and up to Klaipeda in Lithuania.

The project of Europe of the Carpathians was not meant to be opposite to the project of the European Union as a whole. The political leaders and those politicians who participated in the project from divergent states and nations claimed the project of Central and Eastern Europe under the name of Europe of the Carpathians was not created as a bulwark against the European Union. It was vice versa: the members of the project of Central and Eastern Europe wanted to strengthen the cooperation between the states of Eastern and Central Europe, which would positively impact upon the relation of Europe of the Carpathians with all European Union member-states, as through it the developmental gap between west and east would be bridged and sustainable development of the region would be made possible.

The Carpathian strategy implemented in 2013 and put into political practice as of 2014 was the strengthening of the political cooperation via organisations, institutions and through parliamentary exchanges of ideas and concepts of the Carpathian states ${ }^{12}$. Furthermore, there was a focus on the presentation of the Carpathian point of view on the multidimensional problems being faced by the European Union as a whole. Parliamentary groups of parliaments coming from different states of the Central and Eastern Europe were formed to give voice to the issues of the region, and, together with the implementation of the strategy on parliamentary cooperation, there were the intellectual and scientific initiatives, among which the establishment of the University of the Carpathians was mentioned.

The priorities of the Europe of the Carpathians were set out in 2014-2015 and work began on the resolution of the issues brought forth. As a result, the region of Central and Eastern Europe started to gain greater attention within the European Union. Still, the context of the war in Ukraine between Ukraine and

${ }^{11}$ J. Kwieciński, Wspótpraca regionalna państw karpackich, [in:] Europa Karpat. Rzecz o wspótpracy, ed. W. Paruch, Warszawa 2017, p. 63.

${ }^{12}$ The website of The Carpathian Convention, http://www.carpathianconvention.org. 
Russia prevailed amongst the topics addressed by the Europe of the Carpathians. Hence, sub-committees were formed to deal with the context of establishing security in the region. Issues of discussion in 2015 and 2016 included:

1. The geopolitical dangers and the challenges facing Central and Eastern Europe $^{13}$.

2. National states as the values guaranteeing the diversity of Central and Eastern Europe and the Europe of the Carpathians.

3. The Carpathians without borders - to protect heritage, to make real the dreams.

4. The brand of the Carpathians - the strategy for the future.

5. The economy of the Carpathians and the protection of its environment searching for compromise.

6. Infrastructure and investments in the Carpathians - the needs, the projects, the perspectives.

It was noticeable that the scope of the activity of the Europe of the Carpathians expanded the scope of the presence and impact on Carpathian entrepreneurships and intellectual activity. The broad character of the project of Europe of the Carpathians has thus become a socio-political project that made it possible to organise cooperation between the states of Central and Eastern Europe, and ease accession in the European Union for non-members. Through the efforts of Europe of the Carpathians, the European Union became aware of the utmost importance of the area ${ }^{14}$. This was due to several factors, among others, there were thirty states located between Germany and the Russian Federation in the axis of North - South and there were more than 150 million people living in Central and Eastern Europe ${ }^{15}$.

All things considered, the states of the Central and the Eastern Europe are eager to cooperate as they were connected because of:

1. The memory of the loss of the status of a subject and the loss of sovereignty by the superpowers.

2. The strong presence in the public debate of notions of freedom, independence and nation.

3. The perception of a nation as an ethnic-cultural community.

${ }^{13}$ W. Paruch, Europa Karpat - projekt wspótpracy państw Europy Środkowej $i$ Wschodniej, [in:] Europa Karpat. Rzecz o wspótpracy, W. Paruch (ed.), Warszawa 2017, 19.

${ }^{14}$ Karpaty - szanse i perspektywy rozwoju, Brussels 2014.

${ }^{15}$ W. Paruch, Źródła orientacji eurorealistycznej w Polsce. O myśli politycznej Prawa i Sprawiedliwości, [in:] Integracja europejska - polska perspektywa, Z. Czachór, T. Grosse, W. Paruch (eds.), Warszawa 2018, p. 235. 
4. Independent reception and modernisation of political and philosophical ideas in Western Europe.

5. The change of the status of the states and the borders between the states.

\section{The project of the Three Seas Initiative}

The concept of Three Seas implied the participation of the states of Central and Eastern Europe (similarly to the project of Europe of the Carpathians) ${ }^{16}$. Political decision makers within the ruling party in the Republic of Poland since 2015 (Law and Justice) claimed that the reason for the lack of cooperation of the states of Central and Eastern Europe was lack of actions of the government and the Prime Ministers of the Republic of Poland ruling in the period from 2007-2015, the leaders of Civic Platform.

Andrzej Duda emphasised in the presidential campaign in 2015 that the continuation of the policy and strategy in international affairs of Lech Kaczyński, the President of the Republic of Poland (2005-2010) who died in Smoleńsk, must continue. The political programme of Andrzej Duda was in concord with the programme of Law and Justice party.

The core problem of the foreign affairs of the Republic of Poland was a lack of tools for independent realization of the national interest. This was of utmost importance because of geopolitical rivalry, in particular, in the Eastern part of Europe impacting upon the status of the Republic of Poland. The Law and Justice party (after 2015), therefore, claimed the necessity to modify the foreign policy of Civic Platform.

Andrzej Duda presented the concept of the Three Seas at the summit of 12 European states in Dubrovnik (Croatia) on August, 2016 ${ }^{17}$. The concept of the Three Seas referred to the solutions towards Central and Eastern Europe originally put forth in the Interwar Poland by Joseph Piłsudski as Intermarium (Międzymorze). During the initial time of the presidency of Andrzej Duda, the political concept of cooperation amongst the states of Central and Eastern Europe was referred to as ABC (the acronyms for the Adriatic Sea, the Baltic Sea and the Black Sea in the Polish language: Adriatyk, Bałtyk, Morze Czarne). The attendees recognized that cooperation was possible and even advantageous in the sphere of energy security, transport, digitalization and economy - especially in view of the activities of Putin's Russia. Of the last, not every state

${ }^{16}$ P. - E. Thomann, The Three Seas Initiative, a New Project at the Heart of European and Global Rivalries, "Yearbook of the Institute of East-Central Europe", V. 17/2019, p. 31-63.

17 The website of the Internet portal WPolityce, http://wpolityce.pl. 
perceived the threat to be of the same intensity. Therefore, the states agreed to introduce a joint declaration that was not only "against" (Russia), but "for" joint projects of the nations and states of this part of the continent. The representatives of Austria, Bulgaria, Croatia, the Czech Republic, Estonia, Lithuania, Latvia, Poland, Romania, Slovakia, Slovenia and Hungary stressed that through strengthening cooperation in the scope of energy, transport (the establishment of European network) and digital communication, the economy of Central and Eastern Europe would be enhanced. What was of major importance was the context of competitiveness. All were in agreement that this needed to be raised if Central and Eastern Europe wanted to compete with the economy of other, more powerful states.

The issue of global and regional security was key to the cooperation. None of the states of the Three Seas initiative wanted to be a single leader. It was also necessary to stress that the concept of multilateral cooperation of the states of Central and Eastern Europe was not against any of the in situ organizations that promoted security or sustainable development. The representatives of the states claimed that through close cooperation, the economies of the states and, simultaneously, their level of development, would grow. As inter-competition between attendees in trade induced a loss that would not have occurred if cooperation had been in place, the states of Central and Eastern Europe chose to cooperate to boost the region's economy and compete globally. Moreover, via the activities of the institutions and politicians strengthening Central and Eastern Europe, the European Union as a whole would benefit. Helping the European Union would be possible by strengthening European Union as a whole in the context of global relations. Another way of strengthening the European Union would be by strengthening the ties among the members of the newly established platform so that the states and their representatives would work on a given issue for the sustainable development of all.

The outcome of the Dubrovnik (Croatia), August, 2016 meeting was agreement that the strategic cooperation in the territory of the Seas: the Adriatic Sea, the Baltic Sea and the Black Sea needed to be revived. It was also agreed that there was no necessity to establish new parallel institutions or organizations as there was enough pan-national organizations in play through which the Three Seas Initiative could unfold. The mechanisms of the cooperation were also perceived as sufficient, and the sectors where cooperation was assessed as possible and desired were transport, energy, digital communication and economy. Through the initiative, cooperating states also wished to create informal platforms to obtain support where the abovementioned aspects were the core. By choosing the approach of an informal platform, administration and institutionalization was minimized. 
Andrzej Duda expressed in a press conference with the President of Croatia, Kolinda Grabar-Kitarović, that the policy of strengthening the ties was an element that would support the European desire for cohesive policy. The political target and the economical aim of the project was regional economic development and growth in competitiveness of the states participating in the project. Moreover, the elements of shared energy infrastructure would make diversification of gas and petrol supply possible for the states of the region, thereby securing energy independence and security of supply.

Several particular projects where cooperation of the states of Central and Eastern Europe was advantageous came up for discussion before the Declaration of the Three Seas was put into a written form. Here, cooperation would mean in practice changes in the road and railway infrastructure so as to physically link the participating states. This was agreed upon and the outcome were projects such as Via Baltica ${ }^{18}$, and Via Carpathia ${ }^{19}$.

The President of the Republic of Poland underlined that the reason for the meeting was to deepen the integration and cohesion between the states so as to enhance socio-economic life in the region. The ultimate goal was to bring life standards within the region, to that of Western Europe. Hence, the initiative had a practical purpose, and the intent was that it would result in improvements in infrastructure.

The meeting ended with a formal declaration called "The joint statement on the Three Seas Initiative" with the working title of "The statement of Dubrovnik". The authors of the declaration emphasized that connection between the states of Central and Eastern Europe was necessary, especially in the fields of infrastructure and transport. For link enhancement it was pointed out that it was possible to tap into Connecting Europe Facility ${ }^{20}$ and the European Structural and Investment Funds ${ }^{21}$. There were four core dimensions of the cooperation: energy, transportation, communication and economy. Finally, it was explicitly denoted that the cooperation of the states of the Three Seas would be fruitful for the European Union and in the broader context, exempli gratia in transatlantic relations.

\footnotetext{
${ }_{18}$ The website of Portal Samorządowy, http:// www.portalsamorzadowy.pl.

19 The website of Kurier lubelski, http://www.kurierlubelski.pl.

${ }^{20}$ Connecting Europe Facility, https://ec.europa.eu: Digital single market.

${ }^{21}$ European funds for the projects, http://ec.europa.eu: Contracts, grants, funds.
} 


\section{Conclusions and closing remarks}

The initiative of the Three Seas has many similar factors to the concept of Europe of the Carpathians. Both initiatives were established to form interlinking platforms for regional cooperation. Moreover, both were inspired by the Intermarium concept put forward by Joseph Piłsudski.

The strong argument for their creation and success is rooted in the spheres of concrete interest, transportation network and social needs enhancement, environmental cohesion and the ability to cooperate. The projects are complementary to each other and to the work of the European Union. The initiatives have a practical basis and take into account nationality, cultural background and economic fundamentals ${ }^{22}$. Still, there are many fundamental challenges that need to be overcome, one major obstacle being the different national interests of the Three Seas Initiative states ${ }^{23}$.

Krzysztof Szczerski likens the closer integration of the countries of Central and Eastern Europe to membership in a non-exclusive club. Krzysztof Szczerski also claims there are the circles of importance in the foreign affairs of the Republic of Poland and that both initiatives are part of this. The first circle is the Western circle - membership in the EU and NATO. The second circle takes in the Northern part of Europe and the Baltic States and interaction and cooperation with these entities. The third circle of the club is the Eastern circle - Ukraine, Belarus, Russia. The last but not least is the zone of cooperation among the states of Central and Eastern Europe, i.e. Europe of the Carpathians and the Three Seas Initiative. One of the cohesive factors of being in "the club" is transatlantic cooperation. The scope of interest of the diplomacy of the Republic of Poland lies in strengthening the ties of a member of both NATO and the European Union with the states of Central and Eastern Europe, as such actions gives the possibility of greater international standing, in particular, with regard to the EU and the USA.

The projects of Europe of the Carpathians and The Three Seas Initiative were analysed because of one goal - both of them focused on the animation of Central and Eastern Europe. There is a difficulty of overcoming national interests of the states. Furthermore, the formation of a joint goal means spending money in order to receive goals which will help the states to flourish, not necessarily evenly.

${ }^{22}$ T. Łoś-Nowak T., Paradygmat realistyczny - projekcje porzadku międzynarodowego u progu XXI wieku, [in:] Porządek międzynarodowy u progu XXI wieku, R. Kuźniar (ed.), Warszawa 2006, p. 21-56.

${ }^{23}$ M. Górka, The Three Seas Initiative as a Political Challenge for the Countries of Central and Eastern Europe, "Politics in Central Europe", Vol. 14, nr 3, p. 68-70. 
Naturally, the projects are yet to be evaluated as they are somewhat in progress. One of the greatest challenges of the project of The Three Seas Initiative is the role and the patronage of the United States of America and the formation of the cooperation in such a way that The Three Seas Initiative will not be treated as competitive to the European Union.

\section{Bibliography}

\section{1) Sources:}

- Karpaty - szanse i perspektywy rozwoju, Brussels 2014.

- The presentation of the joint declaration in Dubrovnik, http://www.president.pl: Three Seas Initiative.

\section{2) Literature:}

- Cichocki M.A., Lech Kaczyński i polityka zagraniczna, [in:] Lech Kaczyński - portret, M. Karnowski (ed.), Kraków 2010.

- Górka M., The Three Seas Initiative as a Political Challenge for the Countries of Central and Eastern Europe, "Politics in Central Europe", Vol. 14, nr 3.

- Kuchciński M., Stowo wstępne, [in:] Europa Karpat. Rzecz o wspótpracy, W. Paruch (ed.), Warszawa 2017.

- Kwieciński J., Wspótpraca regionalna państw karpackich, [in:] Europa Karpat. Rzecz o wspótpracy, ed. W. Paruch, Warszawa 2017.

- Legutko R., Po pierwsze suwerenność, [in:] Lech Kaczyński, Pamięć i zobowiązanie, Warszawa 2011.

- Łoś-Nowak T., Paradygmat realistyczny - projekcje porzadku międzynarodowego u progu XXI wieku, [in:] Porzadek międzynarodowy u progu XXI wieku, R. Kuźniar (ed.), Warszawa 2006.

- Paruch W., Europa Karpat, Warsaw 2016.

- Paruch W., Europa Karpat - projekt wspótpracy państw Europy Środkowej $i$ Wschodniej, [in:] Europa Karpat. Rzecz o wspótpracy, W. Paruch (ed.), Warszawa 2017.

- Paruch W., Źródta orientacji eurorealistycznej w Polsce. O myśli politycznej Prawa i Sprawiedliwości, [in:] Integracja europejska - polska perspektywa, Z. Czachór, T. Grosse, W. Paruch (eds.), Warszawa 2018.

- Sanecka-Tyczyńska J., Racja stanu we wspótczesnej polskiej myśli politycznej 20012015, Lublin 2018.

- Szczerski K., Zadania dla polityki środkowoeuropejskiej, [in:] Europa Karpat. Rzecz o wspótpracy, W. Paruch (ed.), Warszawa 2017.

- Terlecki R., Europa naszej przyszłości, [in:] Europa Karpat. Rzecz o wspótpracy, W. Paruch (ed.), Warszawa 2017.

- Thomann P. - E., The Three Seas Initiative, a New Project at the Heart of European and Global Rivalries, "Yearbook of the Institute of East-Central Europe", V. 17/2019. 
- Waldenberg M., Kwestie narodowe w Europie Środkowo-Wschodniej. Dzieje. Idee, Warszawa 1992.

\section{3) Websites:}

- Connecting Europe Facility, https://ec.europa.eu: Digital single market.

- European funds for the projects, http://ec.europa.eu: Contracts, grants, funds.

- The website of The Carpathian Convention, www.carpathianconvention.org.

- The website of Karpaty tacza, http://www.karpatylacza.pl.

- The website of Kurier lubelski, http://www.kurierlubelski.pl.

- The website of Portal Samorządowy, http:// www.portalsamorzadowy.pl.

- The website of $W$ meritum, http://www.wmeritum.pl.

- The website of the Internet portal WPolityce, http://wpolityce.pl.

Summary: Cooperating with the countries of Central and Eastern Europe is a means of enhancing the diplomatic standing of Poland (and other states) within the international arena. The effects of such cooperation are of long-term value. The initiators of these initiatives recognized that Central and Eastern Europe is where the geopolitical status of Poland has the greatest positive effect and weight. The core goal of such cooperation in the region is to be active in joint endeavors that are aimed not just at countering the influence of Russia, but at achieving multilateral benefits for all participants.

Keywords: Central and Eastern Europe, cooperation, joint actions, Europe of the Carpathians, The Three Seas Initiative;

\section{Przezwyciężanie konfliktów politycznych i rywalizacji na rzecz współpracy międzynarodowej-projekt Karpat i Inicjatywy Trójmorza}

Streszczenie: Współpraca państw Europy Środkowej i Wschodniej jawiła się jako możliwość lewarowania pozycją Polski na arenie międzynarodowej. Efekty współpracy mogły być mierzalne dopiero w dłuższej perspektywie. Rozumowano, że w Europie Środkowej i Wschodniej rozgrywała się gra o status geopolityczny Polski na arenie międzynarodowej. Celem zasadniczym skutecznej współpracy w regionie miało być wspólne realizowanie projektów, których nie łączyło jedynie działanie przeciw (Rosji), lecz przede wszystkim na rzecz wspólnych projektów, które miały powodować bogacenie się narodów i wielostronne korzyści dla państw uczestniczących w projekcie integrującym i animującym współpracę państw Europy Środkowej i Wschodniej w ramach Europy Karpat i Inicjatywy Trójmorza.

Słowa kluczowe: Europa Środkowa i Wschodnia, współpraca, wspólne przedsięwzięcia, Europa Karpat, projekt Trójmorza; 